\title{
Climatic-change implications from long-term (1823-1994) ice records for the Laurentian Great Lakes
}

\author{
R. A. ASSEL. \\ National Oceanic and Atmospheric Administration, Great Lakes Environmental Research Laboratory, 2205 Commonwealth, Ann Arbor, \\ MI 48105, U.S.A. \\ D. M. ROBERTSON. \\ U.S. Geological Survey, 6417 Normandy Lane, Madison, WI 53719, U.S.A.
}

\author{
M. H. Hoff and J. H. Selgeby \\ U.S. Department of the Interior, National Biological Survey, 2800 Lake Shore Drive East, Ashland, WI 54806, U.S.A.
}

\begin{abstract}
Long-term ice records (1823-1994) from six sites in different parts of the Laurentian Great Lakes region were used to show the type and general timing of climatic changes throughout the region. The general timing of both freeze-up and ice loss varies and is driven by local air temperatures, adjacent water bodies and mixing, and site morphometry. Grand Traverse Bay and Buffalo Harbor represent deeperwater environments affected by mixing of off-shore waters; Chequamegon Bay, Menominee, Lake Mendota, and Toronto Harbor represent relatively shallow-water, protected environments. Freeze-up dates gradually became later and ice-loss dates gradually earlier from the start of records to the $1890 \mathrm{~s}$ in both environments, marking the end of the "Little Ice Age". After this, freeze-up dates remained relatively constant, suggesting little change in early-winter air temperatures during the 20th century. Ice-loss dates at Grand Traverse Bay and Buffalo Harbor but not at the other sites) became earlier during the 1940s and 1970s and became later during the 1960s. The global warming of the 1980 s was marked by a trend toward earlier ice-loss dates in both environments.
\end{abstract}

\section{INTRODUCTION}

Past studies have shown that freeze-up and ice-loss dates are useful indices of climate and climatic change (Palecki and Barry, 1986; Robertson, 1989; Schindler and others, 1990; Skinner, 1993). Long-term freeze-up and ice-loss records at Grand Traverse Bay and Lake Mendota began in the $1850 \mathrm{~s}$ and by about 1890 the average dates reveal a shift to later freeze-up and earlier ice loss. A gradual warming during the 20th century was associated with a second shift to earlier ice-loss dates, starting in about 1940 at Grand Traverse Bay (1940-93) and in 1980 at Lake Mendota (Assel and Robertson, in press). Here we expand on this work by examining four additional sites spread throughout the Great Lakes region. The scope of this study is limited to a first exploratory look at the data. We examine long-term averages and variances (standard deviation) and smoothed plots of the annual data. Our objectives are to (a) identify similarities in the changes in ice cover over the past 200 years throughout the Great Lakes region, (b) describe differences in the ice cover among sites, and (c) qualitatively infer changes in the winter climate throughout the region over the past 200 years.

\section{DATA AND SITE DESCRIPTIONS}

Ice-event dates, i.e freeze-up and ice-loss (break-up) dates, are available throughout the Great Lakes region. Freeze-up can be defined as the date of the first skim ice, the date solid ice forms that lasts until the spring, or something in-between. Ice-loss date can be defined as the date the ice cover breaks up, the date of final loss of ice cover, or something in-between. Since a standard definition thus does not exist for freeze-up or ice loss, climatic analysis of these data is problematic. Albeit with this caveat, we found six sites, spanning virtually the entire region (Fig. 1), that had long-term freeze-up and ice-loss date data sets. These locations were (1) Chequamegon Bay $\left(46.67^{\circ} \mathrm{N}, 90.88^{\circ} \mathrm{W}\right)$ between Houghton Point and Ashland, (2) Grand Traverse Bay $\left(44.76^{\circ} \mathrm{N}, 85.62^{\circ} \mathrm{W}\right)$ from the head of the west arm of the bay to Marion Island, (3) Lake Mendota $\left(43.66^{\circ} \mathrm{N}\right.$, $89.40^{\circ} \mathrm{N}$ ), (4) Green Bay in the vicinity of Menominee, Michigan $\left(45.00^{\circ} \mathrm{N}, 87.64^{\circ} \mathrm{W}\right)$, (5) Buffalo Harbor $\left(42.88^{\circ} \mathrm{N}, 78.90^{\circ} \mathrm{W}\right)$ westward to Long Point, and (6) Toronto Harbor $\left(43.65^{\circ} \mathrm{N}, 79.45^{\circ} \mathrm{W}\right)$ between Toronto Island and the mainland. The period of record and the average water depth for the six sites ranged from 64 to 


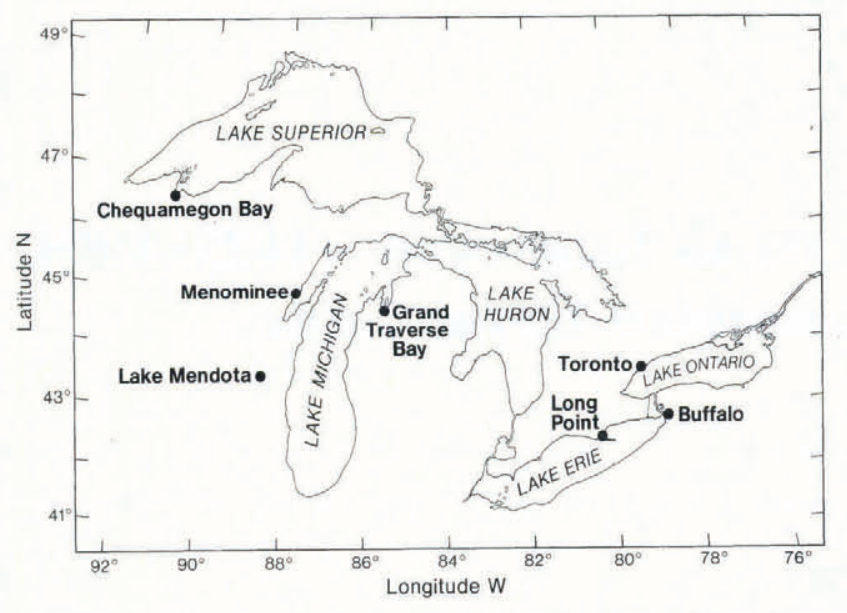

Fig. 1. Site location map.

144 year and from 7 to $46 \mathrm{~m}$, respectively (Table 1 ).

Missing data in the time series were approximated in the following manner. Ice reports from the National Weather Service were used to estimate ice-loss dates for Buffalo Harbor and the east end of Lake Erie for the winters of 1946-50. Grand Traverse Bay freeze-up and ice-loss data (abstracted from Snider (1974)) provide estimated freezeup dates for 1859, 1908, 1909, 1912, 1914, 1918, 1920 and 1921 and estimated ice-loss dates for 1852, 1906, 1908 and 1921. Also, there were 26 winters during which a solid-ice cover did not form in Grand Traverse Bay. The freeze-up and ice-loss dates for these winters were set to 8 March, the average date between the freeze-up and break-up dates for the five winters with the shortest ice durations.

\section{FREEZE-UP AND ICE-LOSS DATES}

The long-term average freeze-up date is latest at Grand Traverse Bay (February "15.5"): 56.1, 57.4 and 58.4d later than at Menominee, Lake Mendota and Toronto Harbor, respectively. The long-term average ice-loss date is latest at Buffalo Harbor (April '23.2"): 1.8, 17.8, 18.5, 22.7 and $24.7 \mathrm{~d}$ later than at Chequamegon Bay, Menominee, Lake Mendota, Grand Traverse Bay and Toronto Harbor, respectively. Air temperature is the single most important climatic variable affecting ice formation and loss, though water depth and water motion are also important site factors. Freeze-up is latest at Grand Traverse Bay because of its large heat storage (46 $\mathrm{m}$ average water depth) and mixing with Lake Michigan. Ice loss is latest at Buffalo Harbor because of ice advection from Lake Erie.

The standard deviations of the freeze-up and ice-loss dates, taken together, are smallest at Lake Mendota (10.9 and $11.1 \mathrm{~d}$ respectively) and are likely to be similarly small at Chequamegon Bay (no data for freeze-up, $9.1 \mathrm{~d}$ for ice loss). Standard deviations in ascending order of magnitude after this are (1) Menominee (10.2 and 17.6d), (2) Grand Traverse Bay, (17.2 and 17.9d), (3) Buffalo Harbor (no data on freeze-up, $19.3 \mathrm{~d}$ for ice loss), and (4) Toronto Harbor (19.6 and 18.1d). Lake Mendota, and Chequamegon Bay are relatively shallow, have minimal mixing from connecting rivers or adjacent water bodies, and thus have a relatively rapid decline in water temperature in autumn, resulting in the observed small variances in freeze-up and ice-loss dates. In the case of the Menominee site, which is also shallow and has a low variance in freeze-up dates, the timing and volume of increased Menominee River flow due to snow melt undoubtedly affect the date of ice loss.

\section{GHANGES AND TRENDS IN FREEZE-UP AND ICE-LOSS DATES, 1823-1994}

To identify changes and trends in the ice data, a 10 year moving average was used to smooth the data. The smoothed data are plotted in the tenth year of the average.

Table 1. Long-term average (Avg.) (in calendar days) and slandard deviation (S.D.) of freeze-up and ice-loss dates

\begin{tabular}{|c|c|c|c|c|}
\hline \multirow[t]{2}{*}{ Location } & Freeze-up & Ice loss & \multirow{2}{*}{ Period of record } & \multirow{2}{*}{$\begin{array}{c}\text { Average depth } \\
\mathrm{m}\end{array}$} \\
\hline & Avg. $\quad$ S.D. & Avg. $\quad$ S.D. & & \\
\hline
\end{tabular}

Southwest Lake Superior Chequamegon Bay

Northeast Lake Michigan Grand Traverse Bay

\begin{tabular}{|c|c|c|c|c|c|}
\hline - & - & 111.4 & 9.1 & $1911-94$ & 7 \\
\hline 46.5 & 17.2 & 90.5 & 17.9 & $1851-1994$ & 46 \\
\hline 355.4 & 10.2 & 95.4 & 17.6 & $1900-63^{*}$ & $<10$ \\
\hline 354.1 & 10.9 & 94.7 & 11.1 & $1856-1994$ & 12 \\
\hline - & - & 113.2 & 19.3 & 190594 & 27 \\
\hline 353.1 & 19.6 & 88.5 & 18.1 & $1823-1919$ & $<10$ \\
\hline
\end{tabular}

Northwest Lake Michigan

Green Bay near Menominee

Southwest Lake Michigan Lake Mendota

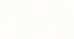

Eastern Lake Erie

Long Point to Buffalo Harbor

Northwest Lake Ontario

Toronto Harbor

353.

* Period for ice-loss date at Menominee was 1900-73. - Data not available.
} 


\section{Changes in freeze-up date}

The general trend shown in Figure 2a is toward later freeze-up dates, with most of the shift occurring before 1900. This is consistent with the end of the "Little Ice Age" around 1850 (Lamb, 1982). Although only three of the locations have records predating 1900, all three indicate later freeze dates after the 1890s. The early data from Lake Mendota and Grand Traverse Bay apparently suggest two different climatic scenarios, that is, freeze-up dates from Grand Traverse Bay suggest a cooling trend with earlier freeze-up dates during the 1860s and early 1870s, while freeze-up dates from Lake Mendota appear to suggest just the opposite. However, the record at Toronto Harbor suggests the earlier ice dates at Grand Traverse Bay were probably just a short-term condition in an overall trend toward later freeze dates. Toronto Harbor's freeze-up dates show a quasi-sinusoidal pattern during the entire period of record (1823-1919). The cause of the sinusoidal pattern is unknown and is currently under investigation.

Freeze-up dates since about 1900 have remained relatively stable. However, there was a greater frequency of winters with mild mid-winter temperatures from the early 1930s to the late 1950s (Assel, 1980) and again from the early 1980s to the early 1990s, resulting in an increased frequency of winters without freeze-up at Grand Traverse Bay which suggests trends toward later freeze-up dates in the 1930s, 1950s, and mid-1980s to early 1990s (Fig. 2a). Similar trends are absent from the time series for Lake Mendota and Menominee, likely because their freeze-up dates represent an earlier November and December) airtemperature integration period. Grand Traverse Bay freeze-up dates represent a later (January) air-temperature integration period, closer to the ice-loss dates.

The changes in average freeze-up dates for Lake Mendota and Grand Traverse Bay occurring around 1890 were quantified in terms of changes in air temperature, using ice models by Assel and Robertson (in press). The results suggest an increase in early-winter air temperatures of approximately $1.5^{\circ} \mathrm{C}$. However, freeze dates were in a period of transition, so air-temperature changes might be expected to be even larger if the period were extended back to the beginning of the Toronto record (1823).

\section{Changes in ice-loss date}

The general trend shown in Figure $2 \mathrm{~b}$ is toward earlier ice-loss dates over the period of record (1823-1994). The trends first toward earlier, then toward later ice-loss dates at Toronto Harbor between the late 1850 s and mid-1870s are due primarily to two winters, 1859 and 1863, with iceloss dates of 27 January and 24 January, respectively. A check of Grand Traverse Bay freeze-up and ice-loss dates for these years (very short ice duration for 1859-23 February freeze-up and 12 March ice loss and no freeze-up for 1863 lends credence to the anomalous 1859 and 1863 Toronto freeze-up and ice-loss dates. The trend toward earlier ice-loss dates at Grand Traverse Bay and Lake Mendota from the beginning of record in the $1850 \mathrm{~s}$ ) to the $1890 \mathrm{~s}$ is in agreement with the end of the Little Ice Age around 1850. The ice-loss record at Toronto Harbor is also in general agreement with the suggested timing of the end of the Little Ice Age: the latest ice-loss dates on record before the late 1850s and a quasicyclic period of earlier ice-loss dates from the mid-1870s to 1919 when the record was unfortunately discontinued.

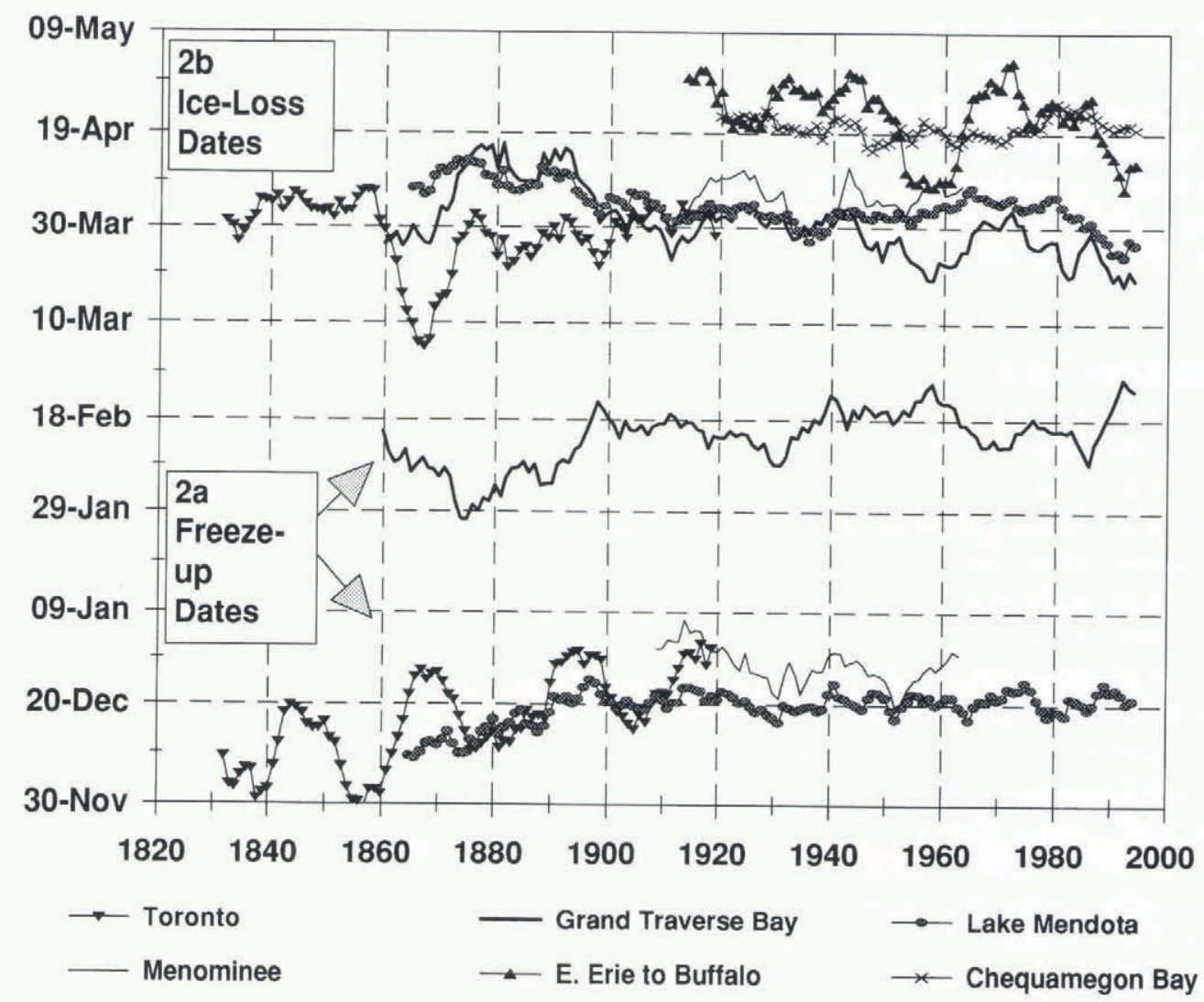

Fig. 2. 10 year moving average (plotted on tenth year) of (a) freeze-up dates and (b) ice-loss dates. 
These data suggest there has been warming during the 20 th century with the 1980s being the warmest decade on record at many locations. The ice-loss dates for Grand Traverse Bay and Lake Mendota remained similar throughout the early 1940s. However, during the 1940 s and $1950 \mathrm{~s}$, ice loss at Grand Traverse Bay became earlier in response to milder mid- to late-winter and early-spring temperatures. Assel and Robertson (in press) found that ice-loss dates for Grand Traverse Bay are strongly related to average March air temperatures which started to increase in about the 1940s and 1950s. Lake Mendota's ice-loss dates did not become notably earlier in the 1940 s and 1950 s because its ice-loss dates are more strongly related to average January-March air temperatures which did not collectively increase until around 1980 (Assel and Robertson, in press).

Changes in ice-loss dates at Buffalo and the east end of Lake Erie were most similar to those at Grand Traverse Bay. These two sites have relatively deep adjacent waters and therefore the potential for mixing with warmer waters. Changes in the ice-loss dates at Menominee and Chequamegon Bay appear to follow the pattern of the iceloss dates of Lake Mendota more than they do those of Grand Traverse Bay, but each site is also unique in its response to climate and climatic change.

Warming in the 1980s and early 1990s affected the entire winter and is reflected in a trend toward earlier iceloss dates at all sites. In fact, during the winters of 1983-92, Grand Traverse Bay did not freeze up in 6 out of these 10 years, a record that is unmatched during any other 10 year period in the 144 years of observations for that site.

The changes in ice-loss dates for Lake Mendota and Grand Traverse Bay that occurred around 1890 were quantified in terms of changes in air temperature using ice models by Assel and Robertson (in press). The results suggest that mid- to late-winter air temperatures increased by approximately $1.1^{\circ} \mathrm{C}$. However, ice-loss dates were in a period of transition, so the air-temperature change would be expected to be even larger if the period were extended back to the beginning of the Toronto record (1823). The results also suggest that mid- to late-winter air temperatures increased by approximately $1.1^{\circ} \mathrm{C}$ after 1940 .

\section{CONGLUDING REMARKS}

Air temperature is the primary climatic variable affecting freeze-up and ice-loss dates, while water depth and mixing with larger adjacent water bodies are also contributory factors affecting ice-event dates. Sites having greater water depth and more exposure to larger bodies of water have later freeze-up dates and greater variance in ice-event dates. The long-term average iceloss date at such sites can be either about the same (Grand Traverse Bay) or much later (eastern end of Lake Erie) than the long-term average date at less exposed sites (Lake Mendota and Toronto Harbor).

The earliest ice records from Toronto, Grand Traverse Bay and Lake Mendota (1823 90) suggest that the winter climate near the Great Lakes prior to 1890 was warming as indicated by a trend toward later freeze-up and earlier ice-loss dates. This is in good agreement with the suggested timing of the end of the Little Ice Age, around
1850. Since about 1890, the average freeze-up dates have remained relatively steady, indicating little change in early-winter air temperatures. Ice-loss dates, however, have continued to become earlier as demonstrated by changes over relatively short periods (1) after 1940 at Grand Traverse Bay, (2) after 1980 at Lake Mendota. The reason for these changes appears to be that ice-event dates at Grand Traverse Bay represent an integration of air temperatures over different time periods and a different lake environment than at Lake Mendota. Ice records at all six sites indicate the warmest decade over the past 200 year occurred in the 1980s.

A key to quantifying the ice-event information in terms of climate change is to develop an objective and accurate ice-event dates model which relates ice events to air temperature or other climatic variable $(\mathrm{s})$. We plan to explore the development of ice-event-air-temperature models to represent air-temperature integration periods associated with freeze-up and ice-loss dates at the four sites not examined by Assel and Robertson (in press). We also plan to examine possible teleconnections between iceevent dates in the different lake environments represented by the six ice sites and possibly at other sites within the Northern Hemisphere by comparing geopotential heights in upper-air data for the Northern Hemisphere.

\section{ACKNOWLEDGEMENTS}

This work was partially funded by the National Oceanic and Atmospheric Administration Office of Global Programs project, "Climate Change and Great Lakes Ecosystems: Retrospective Analysis of Water Temperature, Lake Ice, and Fish Communities". The authors would like to thank P. Knox and D. Clark, the state climatologists for Wisconsin, and P. Hobson of the Traverse City Michigan Chamber of Commerce for providing freeze-up and ice-loss dates for recent winters at Lake Mendota and Grand Traverse Bay, respectively, and R. Rausch of the National Weather Service (NWS) at Buffalo, New York, for NWS ice reports used to estimate ice-loss dates in eastern Lake Erie for 1946-1950. This is Great Lakes Environmental Research Laboratory contribution No. 912.

\section{REFERENCES}

Assel, R. A. 1980. Maximum freezing degree-days as a winter severity index for the Great Lakes, 1897-1977. Mon. Weather Rev. 1089), $1440-1455$.

Assel, R. A. and D. M. Robertson. In press. Changes in winter air temperatures near Lake Michigan during 1851-1993, as determined from regional lake-ice records. Limnol. Oceanogr.

Lamb, H. H. 1982. The Little Ice Age: background to the history of the sixteenth and seventeenth centuries. In Lamb, H. H. Climate, history and the modern world. London and New York, Methuen, 201-230.

Palecki, M.A., and R. G. Barry. 1986. Freeze-up and break-up of lakes as an index of temperature change during the transition season: a case study for Finland. J. Climate Appl. Meteorol., 25 (7), 893-902.

Robertson, D. M. 1989. The use of lake water temperature and ice cover as climatic indicators. Ph.D. thesis, University of Wisconsin at Madison.

Schindler, D. W. and 9 others. 1990. Effects of climatic warming on lakes of the central boreal forest. Science, 250 (4983), 967-970.

Skinner, W. R. 1993. Lake ice conditions as a cryospheric indicator for detecting climate variability in Canada. Glaciol. Data Rep. GD-25, 204240

Snider, C. R. 1974. Greal Lakes ice forecasting. Silver Spring, MD. National Weather Service. (Technical memorandum NWS Ocean Services Division No. 1. 